\title{
TRABALHO-EDUCAÇÃO, ECONOMIA E CULTURA EM COMUNIDADES TRADICIONAIS: ENTRE A REPRODUÇÃO AMPLIADA DA VIDA E A REPRODUÇÃO AMPLIADA DO CAPITAL'
}

\author{
Ana Elizabeth Santos Alves² \\ Lia Tiriba ${ }^{3}$
}

\begin{abstract}
Resumo
Considerando que o trabalho de produção da vida social é em si educativo, apresentamos evidências de práticas econômicas e culturais que, embora atravessadas por mediações do capital, são calcadas nos valores de solidariedade, reciprocidade e cooperação. Referimo-nos a pescadores artesanais do Pantanal mato-grossense, quilombolas de Mato Grosso, ribeirinhos e pescadores artesanais do Pará, a pequenos agricultores e trabalhadores associados da Bahia. Numa abordagem qualitativa, a pesquisa foi desenvolvida por meio de observação participante, registro fotográfico e entrevista semiestruturada. A seleção das comunidades foi feita de acordo com as facilidades de acesso ao campo empírico e às fontes secundárias.
\end{abstract}

Palavras-chave: Trabalho-educação; Povos e comunidades tradicionais; Relações entre economia e cultura.

\section{EDUCATION-LABOR, ECONOMY AND CULTURE IN TRADITIONAL COMMUNITIES: BETWEEN THE AMPLIFIED REPRODUCTION OF LIFE AND THE AMPLIFIED REPRODUCTION OF THE CAPITAL}

\begin{abstract}
Considering life production labor itself is educational; we present evidences of cultural and economic practices that, though crossed by capital mediations, are founded on values such as solidarity, reciprocity and cooperation. We refer to: artisanal fishermen from Paraguay river (in the Pantanal in the state of Mato-Grosso), quilombolas from the state of Mato-Grosso, riverine communities and artisanal fishermen from the Pará, small farmers and associated workers from Bahia. In a qualitative approach, the research was developed through participant observation, photographic record and semistructured interview. The selection of communities was made according to the facilities of access to the empirical field and the secondary sources.
\end{abstract}

Keywords: Education-labor; People and traditional communities; The relationship between economy and culture.

1DOI: https://doi.org/10.22409/tn.16i31.p27375

2Doutora em Educação pela Universidade Federal da Bahia (UFBA). Docente do Programa de PósGraduação em Memória, Linguagem e Sociedade, da Universidade Estadual do Sudoeste da Bahia (UESB). Membro do Museu Pedagógico da UESB. E-mail: ana_alves183@hotmail.com

${ }^{3}$ Doutora em Ciências Políticas e Sociologia (Programa de Sociologia Econômica e do Trabalho), pela Universidade Complutense de Madrid. Professora do Programa de Pós-Graduação em Educação, da Universidade Federal Fluminense (UFF) - Mestrado e Doutorado. E-mail: liatiriba@gmail.com 
O trabalho se constitui como mediação dos seres humanos com a natureza para assegurar a reprodução da vida social, material e simbólica. A premissa do princípio educativo do trabalho nos reafirma a necessidade de compreender em que circunstâncias históricas e em que relações sociais de produção se dá a atividade do trabalho, o que requer, entre outras coisas, responder perguntas clássicas da economia política: o que produzimos? Como produzimos? Por que e para quem produzimos? Como repartimos os frutos do trabalho? Para além da concepção 'economicista', que caracteriza a economia burguesa, vale recuperar o sentido etimológico da palavra economia: do grego Oikos (casa) e nemo (eu distribuo). $\mathrm{Na}$ Grécia Antiga, a Oikonomia era entendida como o conjunto de preceitos sobre a atividade de obtenção dos recursos necessários para a vida em família. Entendemos que, como atividade que se desenvolve no espaço familiar, dentro e fora da unidade doméstica, com o fim de satisfazer as necessidades da família e da comunidade (economia familiar/economia popular/economia comunitária), ou como ciência que rege os processos de produção, distribuição e consumo de uma sociedade, a economia só pode ser compreendida no conjunto das relações sociais que, historicamente, os grupos e as classes sociais estabelecem nos processos de produção da existência humana.

É no ambiente das comunidades tradicionais onde queremos refletir sobre as relações trabalho-educação, entendidas como unidade dialética. Tendo em conta que o trabalho de produção da vida social é em si educativo, nosso propósito é trazer à superfície evidências empíricas de práticas econômicas e culturais que, embora atravessadas por mediações do capital, são calcadas nos valores de solidariedade e cooperação. Essas evidências estão fundadas em modos de vida construídos em torno de relações sociais reproduzidas no interior das comunidades tradicionais, em que pesem a subordinação dessas relações ao modo de produção capitalista.

Propomos, neste artigo, descrever e analisar dados de pesquisa sobre comunidades tradicionais nas regiões norte, nordeste e centro-oeste do Brasil, buscando produzir uma reflexão por meio da literatura crítica sobre modos de vida que convivem, persistem e/ou resistem à lógica da acumulação flexível do capital. 
Optamos pelos termos "povos e comunidades tradicionais" ou "comunidades tradicionais" para nos referir a pescadores artesanais do Rio Paraguai (Pantanal mato-grossense), a quilombolas de Mato Grosso, a ribeirinhos e pescadores artesanais do Rio Tocantins (Cametá/Pará), a trabalhadores(as) rurais que se autodenominam pequenos agricultores e a suas famílias que moram na microrregião de Vitória da Conquista (Bahia) e a trabalhadores rurais associados que residem na região cacaueira de Camacã (no sul da Bahia) ${ }^{3}$.

Seguindo uma abordagem qualitativa, a pesquisa foi desenvolvida por meio de observações participantes, registros fotográficos e entrevistas semiestruturadas. A seleção das comunidades pesquisadas e dos sujeitos participantes foi feita de acordo com as facilidades de acesso ao campo empírico pelas pesquisadoras. Este artigo é fruto da articulação de duas pesquisas: "Reprodução ampliada da vida: dimensões educativas, econômicas e culturais do trabalho de produzir a vida associativamente", coordenada por Lia Tiriba (2016), e "A centralidade do trabalho e da educação nas histórias de vida de mulheres e homens em comunidades rurais", coordenada por Ana Elizabeth Santos Alves (2014-2017), com financiamento do CNPq. Os dados empíricos citados são oriundos das análises dessas e de outras pesquisas.

\section{Economia, cultura e hegemonia: alguns pontos de partida}

Poderia parecer redundante dizer que no modo de produção capitalista são hegemônicas as relações capitalistas de produção da vida social. Entretanto, acreditamos que, tanto E. P. Thompson (1981), como Raymond Williams (2011) nos ajudam a aprofundar o entendimento dessa assertiva marxiana - o que, para nós, justifica, epistemologicamente, a opção por eleger os modos de vida em comunidades tradicionais como objeto de reflexão.

Sobre a formação econômica e cultural da classe trabalhadora, mediada pela experiência humana, individual e coletiva, Thompson nos diz que

\footnotetext{
${ }^{3}$ A referência aos trabalhadores rurais associados da região cacaueira diz respeito a trabalhadores assentados pelo INCRA em duas fazendas desapropriadas pelo governo federal, no município de Camacã, BA, no final dos anos 1990.
} 
[...] a classe se delineia segundo o modo como homens e mulheres vivem suas relações de produção e segundo a experiência de suas situações determinadas, no interior do 'conjunto de suas relações sociais', com a cultura e as expectativas a eles transmitidas e com base no modo pelo qual se valeram dessas experiências em nível cultural (THOMPSON, 2001, p. 277).

Refutando o reducionismo econômico e reafirmando as relações dialéticas entre base e superestrutura, ao se referir ao "conjunto das relações sociais", Thompson quer chamar atenção para a necessidade de se considerar as formas como as pessoas apreendem as relações sociais capitalistas (que são hegemônicas) e, também, outras relações econômicas e culturais no fazer-se de homens e mulheres trabalhadores(as). Nessa perspectiva, a cultura popular se constitui como elemento indispensável para análise das experiências de classe ocorridas ao longo da 'formação da classe operária na Inglaterra'. Concebendo a história como "processo estruturado", em Costumes em comum, Thompson (1998) analisa as práticas culturais como parte integrante da "economia moral das multidões", em defesa de um modo de vida que se contrapõe ao modo de vida capitalista.

Em nossos estudos, parece-nos fundamental a contribuição de Raymond Williams em relação à hegemonia, cujo conceito apreendeu do pensamento de Antonio Gramsci e que é chave para uma concepção materialista de cultura. Para Williams, hegemonia não pode ser entendida como um conceito estático, dado que suas estruturas internas são complexas e precisam ser constantemente desafiadas e, portanto, precisam ser recriadas e defendidas continuamente. Como um conjunto de significados e valores que são experimentados enquanto práticas e que se confirmam mutuamente, a hegemonia abrange muitas áreas da vida. Ela constitui "um sentido absoluto por se tratar de uma realidade vivida além da qual se torna muito difícil para a maioria dos membros da sociedade mover-se" (WILLIAMS, 2011, p. 53). No entanto, é preciso considerar o que acontece "fora" do modo dominante, pois como afirma Williams (2011, p. 59):

Nenhum modo de produção e, portanto, nenhuma sociedade dominante ou ordem da sociedade e, destarte, nenhuma cultura dominante pode esgotar toda gama de prática humana e da intenção humana (essa gama não é o inventário de alguma "natureza humana" original, mas ao contrário, é aquela gama extraordinária de variações práticas e imaginadas pelas quais seres humanos se veem como capazes). 
Nos Estados da Bahia, Mato Grosso e Pará, não seria coincidência encontrar nas comunidades tradicionais o que Raymond Williams chama de "culturas residuais" e "culturas emergentes". Para não considerar como arcaicas ou atrasadas as culturas nessas comunidades e, muito menos, cair no romantismo em relação aos modos de vida que lá se configuram, é importante estar atento para perceber que, na prática, os modos de vida tanto podem ser 'alternativos', como podem ser 'opositores' ao modo de produção capitalista. Sobre as dificuldades de superar a hegemonia do capital sobre o trabalho, precisamos considerar que:

As dificuldades da prática humana fora ou em oposição ao modo dominante são obviamente reais. Elas dependem muito da prática estar ou não em uma área em que a classe e a cultura dominantes têm um interesse e uma participação. Se o interesse e a participação são explícitos, muitas novas práticas serão alcançadas e, se possível, incorporadas - ou então extirpadas com extraordinário vigor (WILLIAMS, 2011, p. 59-60).

A partir das contribuições de Thompson e Williams, acreditamos que as comunidades tradicionais são parte integrante e constitutiva dessas "variações práticas e imaginadas", o que nos faz eleger seus modos de estar no mundo, considerando os nexos entre economia e cultura como pares dialéticos. Não se trata de entender questões de "ordem econômica" ou de "ordem cultural", mas de apreender as relações econômico-culturais que tecem os fios da produção da existência humana, no intercâmbio com outros seres da natureza.

\section{Entre quilombolas, ribeirinhos e pescadores: mediações do capital e do trabalho de produzir a vida associativamente}

Mediação, contradição e particularidade são categorias do materialismo histórico que nos conduzem à análise da totalidade social, onde jovens, adultos e crianças, das comunidades tradicionais, (de)formam-se na luta pela reprodução ampliada da vida. No livro 17 contradições e o fim do capitalismo, David Harvey (2016) analisa a crise atual do capitalismo no século 21, a qual - assim como todas as suas crises - é essencial para sua reprodução: "como disse Marx certa vez, as crises mundiais sempre foram 'a concentração real e o ajuste forçoso de todas as contradições da economia burguesa'” (HARVEY, 2016, p. 12). Para compreender os 
problemas que nos desafiam, o autor nomeia as contradições do capitalismo como "fundamentais", "mutáveis" e "perigosas".

Como "contradições fundamentais", Harvey destaca a contradição entre valor de uso e valor de troca, entre o valor social do trabalho, sua representação pelo dinheiro e a apropriação privada da riqueza, as quais geram a própria unidade contraditória entre produção e realização. São aquelas que são constantes do capital, em qualquer época ou lugar e cujas leis básicas se mantêm ao longo da história do capitalismo. São elas que "definem o terreno político no qual podemos delimitar uma alternativa para o mundo criado pelo capital" (HARVEY, 2016, p. 90). Entre as "contradições mutáveis", ou seja, aquelas que resultam de determinadas circunstâncias do desenvolvimento das forças produtivas, o autor apresenta a questão do avanço da tecnologia, a descartabilidade humana, as formas desiguais de produção do espaço e de desenvolvimentos geográficos, as disparidades de renda e riqueza, entre outros. Quanto às "contradições perigosas", tanto para o capital, como para a humanidade, ressalta a relação do capital com a natureza que, em nome de um crescimento exponencial infinito, é remodelada e reconfigurada pelas ações do capital, ameaçando a vida no planeta. Para ele,

[...] o ecossistema é construído a partir da unidade contraditória entre capital e natureza, da mesma maneira que a mercadoria é a unidade contraditória entre valor de uso (sua forma material e "natural") e valor de troca (sua valoração social) (HARVEY, 2016, p. 230).

Em outras palavras, "o capital transformou a questão ambiental em um grande negócio. As tecnologias ambientais são cotadas a valores altíssimos nas bolsas de valores" (HARVEY, 2016, p. 231).

É no ambiente das contradições fundamentais, mutáveis e perigosas do sistema capital que os povos e as comunidades tradicionais resistem e afirmam seus modos de vida e o direito de decidir sobre seus destinos. Mas antes de tudo, é preciso dizer que o Brasil é considerado o maior consumidor de agrotóxicos do mundo: em 2010, foram utilizados mais de 800 milhões de litros em nossas lavouras, cabendo o consumo de 5,2 litros a cada brasileiro. Neoextrativismo, monocultura, uso crescente de inseticidas, de herbicidas e de outros agrotóxicos são alguns dos ingredientes da chamada 'revolução verde', cujo objetivo é promover desenvolvimento das forças produtivas do capital. Em busca de obter um rendimento 
da terra superior ao dos cultivos tradicionais, as monoculturas são geneticamente uniformes (cultivos homogêneos de variedades de laboratório) e, a cada safra, o produtor precisa adquirir novos pacotes tecnológicos. Ao poluir as águas, extinguindo espécies nativas e grande parte da fauna dos rios, o modo de produção capitalista caminha no sentido contrário à preservação da vida, causando desequilíbrios ecológicos na cadeia alimentar. Sendo o avesso dos sistemas agrícolas tradicionais, o agronegócio desconsidera, ou coloca a seu favor os conhecimentos tradicionais sobre a interação solo-planta-água-ecossistema.

No Estado de Mato Grosso, encontramos 45 etnias, localizadas em 78 terras indígenas, que lutam pela demarcação e proteção de suas terras. Resistem também 68 comunidades pantaneiras e 69 comunidades quilombolas, espalhadas nos biomas do Pantanal, Cerrado e Amazônia (SATO et al., 2013). Nesse Estado, considerado a capital do agronegócio, verificam-se a exploração sobremaneira dos ecossistemas, a degradação da diversidade e de homens e mulheres, cuja racionalidade econômica e cultural dos modos de vida se distingue da lógica do modo capitalista de produção da vida social. A riqueza ambiental e cultural que ali se constitui, torna-se objeto de resistência e de luta contra a espoliação. Sobre os conflitos sociais ambientais, foi verificada, em 2012, a existência de "194 pontos de ocorrência, com 359 causas propulsoras, sendo 68 desses pontos denunciados como ameaças de morte e 12 locais sinalizam a prática desumana do trabalho escravo", o que nos possibilita constatar o "cenário de insustentabilidade social e ecológica do modelo de desenvolvimento instituído em MT" (SATO et al., 2013, p. 124).

Em Mato Grosso ${ }^{4}$, Camilla Neves (2013) analisou os significados da produção associada para moradores da Comunidade Quilombola de Capão Verde, localizada no município de Pocomé. Os dados revelam que não são poucos os problemas encontrados, entre eles a forte influência do SEBRAE, em relação à perspectiva empreendedora da agroindústria de derivados de banana da terra; a saída dos mais jovens em busca de trabalho na cidade; além da escassez de água encanada:

\footnotetext{
${ }^{4} \mathrm{O}$ Grupo de Estudos e Pesquisas sobre Trabalho e Educação (GPTE/UFMT), coordenado pelo Prof. Dr. Edson Caetano, tem analisado diversas comunidades tradicionais no Estado de Mato Grosso, entre elas citamos a Comunidade tradicional pantaneira, de São Pedro de Joselândia; a Comunidade tradicional do Imbé; a Comunidade quilombola Campina de Pedra; a Comunidade quilombola Capão Verde; o Assentamento Rural 14 de Agosto, em Campo Verde; as Comunidades tradicionais de Cáceres, aldeias da etnia Chiquitano.
} 
“Agora nós tamo nessa peleja aqui resolvendo questão de água. Fez rede, mas a água não chegou na minha casa, nas outra vai água tudinho insuficiência de falta de água entre outros" (CATARINO apud NEVES, 2013, p. 151) ${ }^{5}$. O descaso do poder público se manifesta em todas as esferas da vida. Quando não são suficientes o cuidado e a solidariedade dos moradores em relação às pessoas que adoecem, é preciso buscar atendimento médico:

Se precisa fazê exame vai lá no Chumbo. Nós não tem carro próprio, aí é difícil demais pra ir; o ônibus não passa lá. Prá nóis é até mais fácil ir prá Cuiabá, porque aqui nóis mora na beira da avenida, pega o ônibus e vai direto. Prá ir para Poconé nóis tem que ir lá no entroncamento de Livramento, é difícil (MARIA ALBERTINA apud NEVES, 2013, p. 106).

No Pantanal mato-grossense, onde existem cerca de 1.000 espécies de aves, 300 espécies de mamíferos, 480 espécies de répteis e 300 espécies de peixes, 0 sistema capital tem ameaçado a flora, a fauna e o modo de vida dos ribeirinhos e dos pescadores artesanais. No trabalho de campo realizado no Rio Paraguai, adentramos numa pequeníssima parte do patrimônio ambiental do Sistema Paraguai-Paraná de Zonas Úmidas, que abrange Brasil, Argentina, Bolívia, Uruguai e Paraguai. A beleza exuberante do Pantanal vem acompanhada de outras paisagens: plantações de soja, eucalipto, pinos e outras monoculturas; utilização sem limites de agrotóxicos e fertilizantes químicos; crescimento do rebanho bovino e suíno; poluição e contaminação dos recursos hídricos causadas por dejetos industriais, em especial pelos frigoríficos. Isso, sem falar dos empreendimentos futurísticos do hidronegócio: os projetos para construção de mais de 100 usinas hidrelétricas; a eminente ativação da Hidrovia Paraguai-Paraná, para escoamento da produção agropecuária; a crescente construção de barragens e de tanques para a piscicultura, nas lâminas d'água da região, etc. A ganância voraz do capital tem alterado o pulso de inundações na planície do Pantanal, prejudicando a biodiversidade da região, limitando a migração de peixes que sobem os rios para a reprodução e retendo organismos aquáticos importantes para a alimentação dos seres humanos e não humanos (TIRIBA; SANTANA, 2017).

\footnotetext{
${ }^{5}$ A citação é um fragmento de entrevista colhida por Camila Neves na pesquisa de campo com um morador de comunidade na região de Mato Grosso.
} 
Mediados pelo capital e pelo trabalho de produzir a vida associativamente (TIRIBA; FISCHER, 2013), mulheres e homens das comunidades tradicionais resistem, estabelecendo intensas relações com a natureza. Como lembra Valter Cruz (2012, p. 598), "esses grupos possuem extraordinária gama de saberes sobre os ecossistemas, biodiversidade e os recursos naturais [...]" e que "[...] o acervo de conhecimento está materializado no conjunto de técnicas e sistemas de uso e manejo dos recursos naturais, adaptado às condições do ambiente em que vivem". É por isso que, para o pescador Sérgio, do Pantanal Mato-grossense, "é como se a [gente] fosse um biólogo, na verdade". Para Seu Justino, que está atento ao caminho das águas e dos peixes, é um equívoco antecipar a Piracema para o mês de outubro:

Sabe por quê? Porque natureza é natureza. A chuva pode vir mais cedo ou vir mais tarde. Eu penso é isso. De repente, [a temporada de pesca] fecha mês que vem. De repente a chuva não vem. O peixe que vai sofrer. Não somos nós. O peixe não vai subir. A ova vai ficar na barriga dele. Se tiver água, ela vai subir. Se não tiver, ela não vai subir. É isso o que vale (JUSTINO apud TIRIBA; SANTANA, 2017, p. 70).

Figura 1 - Pescador artesanal do Pantanal Mato-grossense.

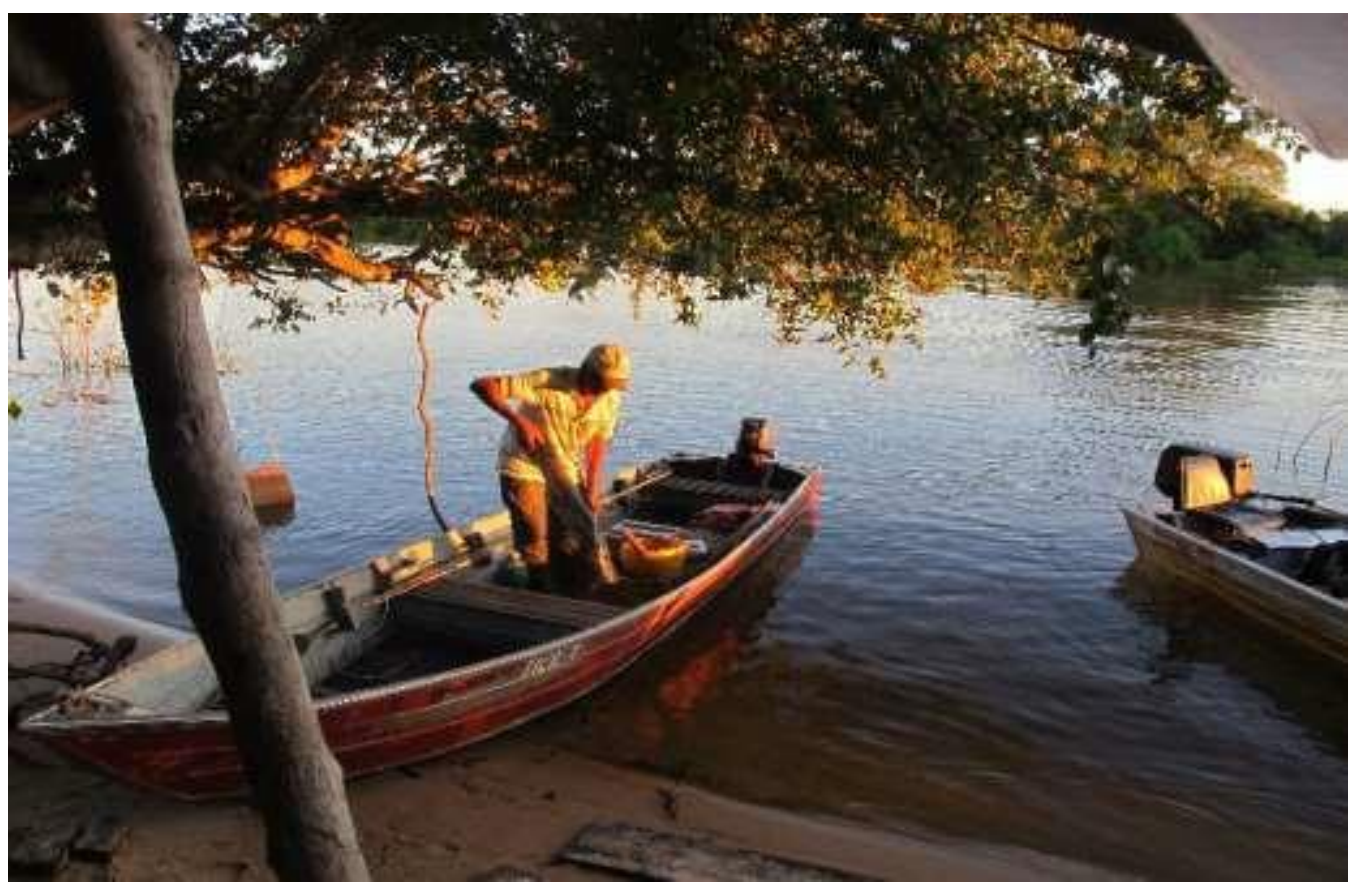

Fonte: Foto de Lia Tiriba (2016). 
Figura 2 - Acampamento de pescadores artesanais do Pantanal Mato-grossense.

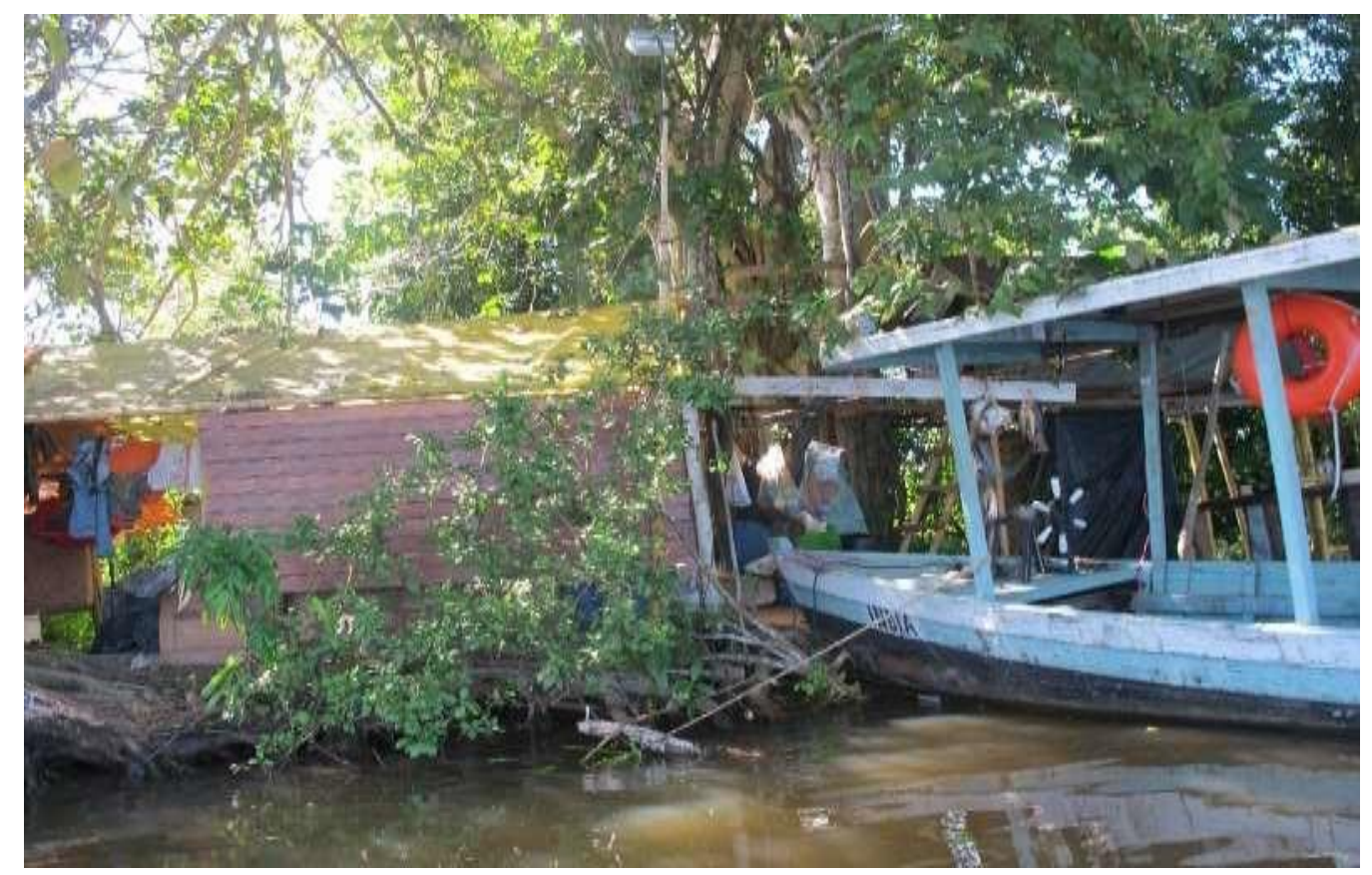

Fonte: Foto de Lia Tiriba (2016).

No cotidiano da pesca, é preciso se proteger de muitos perigos, entre eles, o perigo da Onça Pintada e "do bicho-homem, ou melhor, dos homens-de-negócio que se enriquecem à custa da exploração do trabalho alheio" (TIRIBA; SANTANA, 2017, p. 70). Para driblar a lógica perversa dos atravessadores e de outros representantes dos interesses do capital, além de se vincular à Colônia de Pescadores Z-02, um grupo de pescadores e pescadoras têm se mobilizado, com o apoio do Núcleo UNEMAT - UNITRABALHO, da Universidade do Estado do Mato Grosso, para organizar uma cooperativa que fortaleça laços de solidariedade e reciprocidade.

Em Cametá, no Estado do Pará, os pescadores artesanais do Rio Tocantins sabem Prá onde sopram os ventos (BARRA, 2015). Depois da criação da Usina Hidroelétrica de Tocantins e de outras ações de empresários vinculados ao agronegócio e ao hidronegócio, os impactos ambientais foram desastrosos. A usina foi projetada na época da ditadura empresarial-militar e sua construção iniciada em 1975. O objetivo da política de modernização conservadora foi tornar navegável um trecho do Rio Tocantins, gerar energia para a região, em especial para siderúrgicas de produção e exportação de alumínio. Ao desviar o curso do rio e provocar inundações numa área de $2.830 \mathrm{~km}^{2}$, a obra expulsou centenas de família das comunidades quilombolas, indígenas, ribeirinhas e pequenos trabalhadores rurais, 
remanejando mais de 25 mil pessoas. Além disso, a construção da barragem, fechada em 1984, repercutiu em praga de mosquitos, em surto de malária, entre outros $^{6}$. Em síntese,

[...] a instalação desse projeto alterou profundamente o modo de vida dos habitantes dessa área, principalmente por terem incluído em seu cotidiano outras formas de relacionamento com os novos atores que chegavam à região: as grandes empresas, particularmente a Eletronorte (DIEGUES, 1999, p. 55).

A cerca de 200 km ao norte de Tucuruí, às margens do Rio Tocantins, encontra-se o município de Cametá, com suas esplendorosas ilhas, igarapés e povoados. Sobre os sentidos do trabalho para o pescador artesanal, Barra (2015, p. 26) nos indica que "o rio e a terra são compreendidos não só como espaço de trabalho, mas também de moradia, de sobrevivência, de convivência comunitária e de educação". No entanto, a deterioração do meio ambiente faz com que os ribeirinhos do Baixo Tocantins, tanto de terra firme, quanto das ilhas, tenham que buscar outras formas de trabalho.

Em julho de 2017, participamos de uma reunião com pescadores, lideranças locais, além de professores e pesquisadores da Universidade Federal do Pará/Campus de Cametá. As necessidades de complementar a renda familiar pareciam ser tantas, que um antigo pescador se mostrou muito preocupado com o futuro das crianças e jovens ribeirinhos, sugerindo que a escola passasse a dar aula de informática para os alunos, ou seja, preparasse-os para um mundo de trabalho estranho aos ribeirinhos.

Em sua tese de doutorado, Egídio Martins (2017) analisa, exaustivamente, as condições de vida e trabalho dos pescadores de Cametá. O relato de um pescador artesanal diz que eles necessitam de ajuda, "[...] porque a dificuldade é grande, não existe como a gente somente pescar para sustentar a família diretamente do Baixo Tocantins. Saio para mariscar, por exemplo, com a malhadeira, às vezes não consigo do almoço" (Pescador 5 apud MARTINS, 2017, p. 143). Para assegurar melhores condições de vida e de trabalho, os pescadores artesanais reivindicam do Estado seus direitos sociais. Foi fundamental a organização e a resistência dos(as)

\footnotetext{
${ }^{6}$ Sobre as consequências, 25 anos depois da construção da Hidrelétrica de Tucuruí, ver o vídeo Tucuruí - a saga de um povo, produzido pelo Movimento Nacional de Atingido por Barragens (2010). Disponível em: <https://www.youtube.com/watch?v=NSm8J3CUsOU>.
} 
trabalhadores(as) em torno da Colônia de Pescadores Z-16 que, até o final da década de 1980, atendia aos interesses dos atravessadores e de outros representantes do capital.

Com ajuda da pastoral dos pescadores, começamos a reunir, a gente reunia três, quatro, cinco, vezes, debatendo, discutindo as formas, de conquistar a Colônia. Dessas nossas reuniões surgiu uma reunião grande, realizada no sindicato dos trabalhadores rurais, eu não estava, mas eu soube que queriam brigar, teve briga, o pessoal do Lilico se revoltaram contra o nosso pessoal (Pescador 3 apud MARTINS, 2017, p. 116).

Além de outras formas associativas de trabalho, a Colônia de Pescadores Z16 estimulou a criação, em 2008, da Cooperativa de Empreendimentos Autogestora de Cametá (COOPAC), que produz e comercializa palmito, além de manter um tanque de peixes, camaroeira, plantio de banana e cupuaçu. Segundo um dos pescadores "[...] o projeto da fábrica de palmito, de gelo, o laboratório de alevinos, tudo é resultado da Colônia, todos estão funcionando" (Pescador 3 apud MARTINS, 2017, p. 143).

Figura 3 - Cametá, margens do Rio Tocantins/Pará.

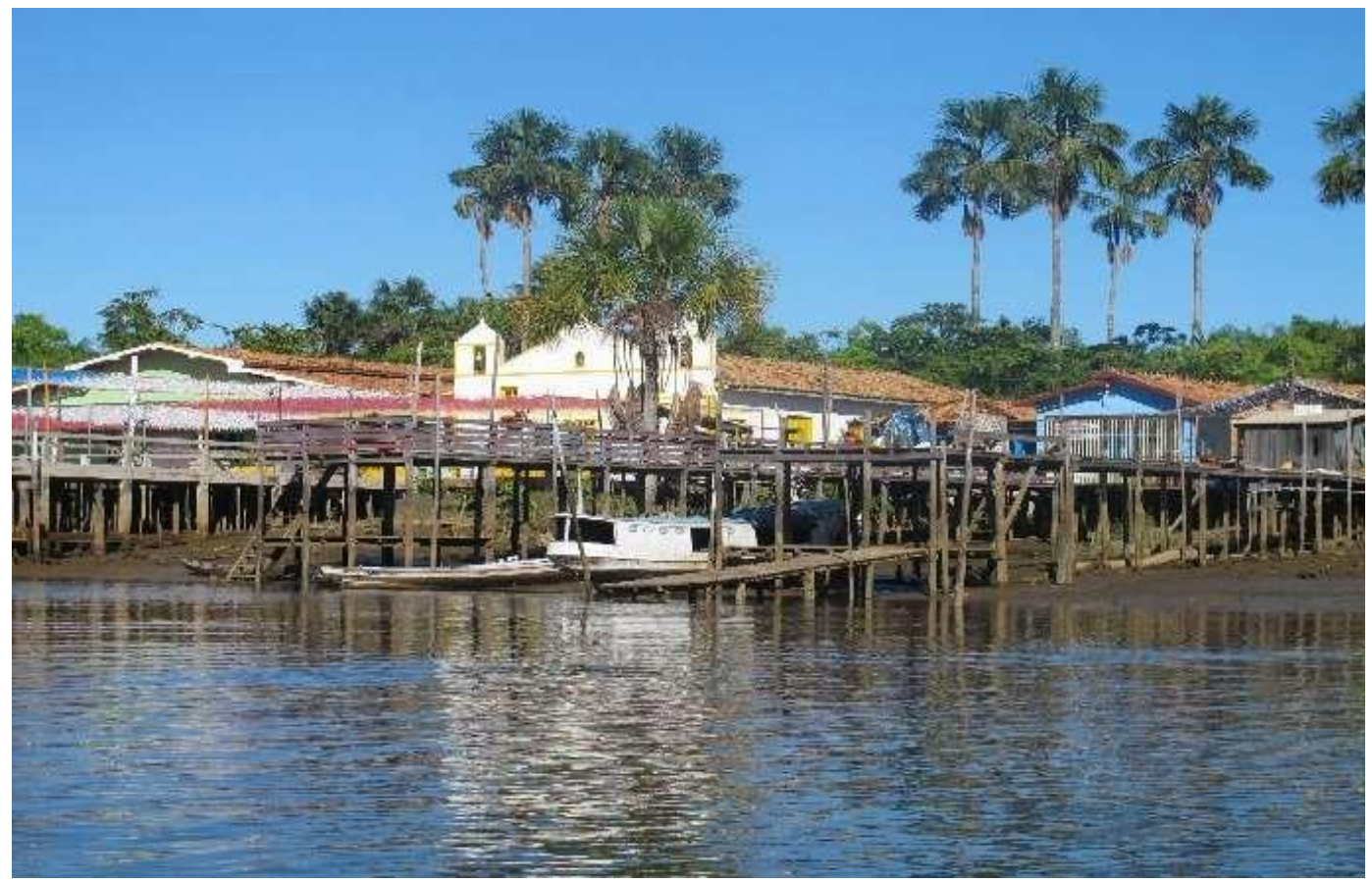

Fonte: Foto de Lia Tiriba (2017). 
Figura 4 - Embalagem do Palmito produzido pela COOPAC.

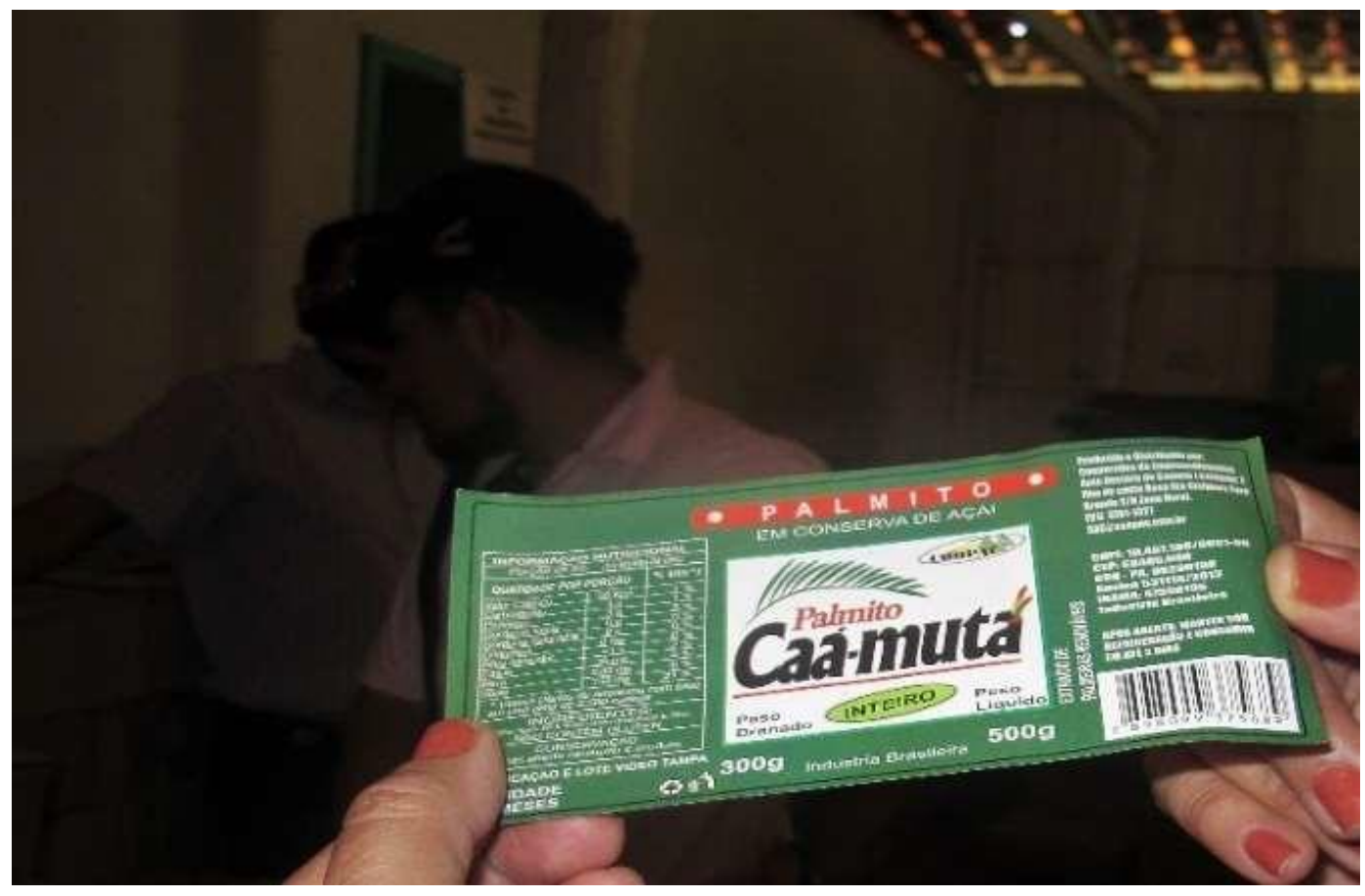

Fonte: Foto de Lia Tiriba (2017).

É continua a luta para que prevaleçam os interesses do trabalho e não do capital. Os embates ocorrem, inclusive, nos momentos de eleição dos coordenadores de base, cujo trabalho é encaminhar as demandas da comunidade, estimular sua participação nos cursos de formação e em outras atividades promovidas pelo grupo. Orgulhoso, um pescador conta que quando se tornou coordenador de sua comunidade passou "[...] a contribuir na conscientização do povo da importância que tinha o nosso direito [...] às vezes ficava velho na pesca era quando ia se aposentar, não tinha entidade nenhuma para se representar" (Pescador 6 apud MARTINS, 2017, p. 150). Os pescadores considerados 'capitalizados' representam uma constante ameaça aos pescadores artesanais:

O desafio daqui para frente é não deixar a 'peteca cair', segurar a Colônia nas nossas mãos, [...] já tem uma chapa formado, para disputar a eleição da Colônia, tem um pessoal que já estão capitalizado, não querem ser considerado pescador artesanal, aquele que não tem o grande capital, pescador artesanal tem que ter barco de dez tonelada para baixo, pescador que se diz pescador capitalizado, tem grande barco e outras coisas, comércio etc. por isso que tem essa polêmica aí (Pescador 3 apud MARTINS, 2017, p. 160). 
Os saberes adquiridos no processo de trabalho e nos processos formativos promovidos no âmbito da Colônia de Pescadores Z-16 têm sido importantes para enfrentar a força do vento, que sopra mais a favor do capital e muito menos a favor de mulheres e homens trabalhadores que povoam a região. No que diz respeito à conquista do Seguro Defeso e ao Acordo de Pesca, Doriedson Rodrigues (2015, p. 44) lembra que, "ao tomarem o saber sobre o Estado e suas políticas assistencialistas, [os pescadores] fortalecem-se politicamente enquanto classe para si e percebem nesses elementos, fatores importantes para manter a coesão enquanto classe" Para Martins,

[...] as experiências construídas na práxis política dos pescadores da Z-16 estão imbuídas de contradição, de modo que, ao lutarem para dar conta de sua subsistência, lutam também contra as ações das ideologias da classe que detém o poder dos meios de produção, mas, ao mesmo tempo, necessitam dessa classe, por meio do Estado, para subsidiar sua condição de existência (MARTINS, 2017, p. 49).

Enfim, ribeirinhos, pescadores e quilombolas lutam como povos e comunidades tradicionais e como classe trabalhadora para assegurar modos de vida fundados em relações de solidariedade. Sobre formas de sociabilidade que fortalecem a associatividade entre homens e mulheres trabalhadoras, John Comerford (2003) ressalta a importância dos laços existentes de parentesco, compadrio, amizade e pertencimento religioso. Tomando de Bailey o conceito de "comunidade moral", centrada na construção de relações de reputação, indica que, no processo de luta em defesa dos direitos sociais, os laços vão se fortalecendo no interior das comunidades rurais e dos sindicatos de classe, constituindo-se como "comunidade moral militante". Mas, é preciso não mistificar as relações que se estabelecem nas comunidades tradicionais. Como nos indica Thompson (1998), embora o sentimento de pertencimento ao grupo seja um elemento indicativo da existência de práticas e de valores compartilhados, a cultura não se constitui como campo de consenso, mas como campo de conflitos ${ }^{7}$.

\footnotetext{
${ }_{7}$ Pesquisas realizadas no Brasil, no campo da antropologia e da sociologia, inspiradas em teorias funcionalistas, definiam uma Comunidade "como um lugar de igualdade, integração e afeto, sem levar em conta os conflitos, as mudanças e as hierarquias" (ALVES; SILVA, 2013, p. 43). Esses estudos podem ser conhecidos em coletânea organizada por Florestan Fernandes (1972). No Estado da Bahia, por exemplo, no final dos anos 1940, realizaram Estudos de Comunidade na região da Chapada Diamantina, especialmente nas cidades de Rio de Contas e Nossa Senhora do Livramento
} 


\section{Modos de vida e sociabilidade em comunidades tradicionais rurais}

"Modos de vida" é um conceito multidimensional e de definição incerta, em função de diversas concepções teórico-metodológicas presentes no campo das ciências sociais (BRAGA; FIÚZA; REMOALDO, 2017). Para a finalidade de nossa análise, neste texto, 'modos de vida' é compreendido como um conjunto de práticas sociais cotidianas de um determinado grupo social, relacionadas ao mundo do trabalho, à vida familiar, ao consumo e ao lazer, articuladas com a sociedade em geral (GUERRA, 1993). Os modos de vida, em comunidades tradicionais rurais, remetem-nos a formas de existir do camponês na luta diária em busca de sobrevivência, nas práticas rotineiras para manutenção e reprodução da vida construída em torno da terra, da família e do trabalho, mediado por relações de solidariedade com parentes e vizinhos (MARQUES, 2004). A "ajuda mútua" visa o "bem comum" da comunidade. Materializa-se nas trocas cotidianas de ferramentas de trabalho, nos mutirões para plantio e para colheita, na manutenção de estradas, pontes, na organização de casamentos, batizados e festividades que acontecem após a realização dos trabalhos coletivos.

Os saberes do trabalho são produzidos cotidianamente. A cultura é transmitida de geração em geração. Como Tardin, podemos dizer que, em seu dia a dia, o ser camponês estabelece fortes relações com a natureza e que sua forma de estar no mundo exige

conhecimentos amplos, entre outros, sobre as plantas cultivadas e os animais silvestres criados; saberes sobre produção, proteção, conservação, transformação e armazenagem; sobre usos que incluem a gastronomia [...]; sobre o clima, o vento, a temperatura, a chuva, a seca, a geada; sobre as estações do ano e o ciclo lunar; sobre fertilizantes, ferramentas e máquinas de trabalho; sobre construção; e sobre produção artesanal, roupas, calçados, adornos (TARDIN, 2012, p. 180).

Em comunidades tradicionais rurais da região de Planalto $\left(\mathrm{BA}^{8}\right)$, os modos de vida se caracterizam por vínculos estreitos de homens e mulheres com a natureza,

de Brumado, no desenvolvimento do "Programa de Pesquisas Sociais Estado da Bahia" em parceria com a Universidade de Columbia (EUA).

${ }^{8}$ Análises sobre as comunidades tradicionais rurais de Planalto (BA) já foram objeto de outras publicações como Alves (2013, 2016). 
por relações de parentesco e de vizinhança com fortes laços comunitários, fundadas em princípios de sociabilidade que visam a "construção política de um 'nós' que se contrapõe ou se reafirma por projetos comuns de existência e coexistência sociais" (WELCH et al., 2009, p. 13), na conservação de costumes e tradições.

A sociabilidade entre os grupos familiares se manifesta na "ajuda mútua" no trabalho doméstico, na roça e na cooperação em acontecimentos importantes, como a realização de festas de casamento e a construção de casas. Ao mesmo tempo, evidenciamos que os modos de vida também são tecidos no âmbito da sociabilidade do capital, por meio da inserção produtiva no trabalho assalariado em outras terras ou nas cidades. A narrativa de uma das moradoras retrata bem essa situação:

Nos tempo das plantações mesmo as chuvas faltam, outra hora quando dá uma chuvinha a gente pranta, o tempo levanta. Eles acham melhor trabalhar fora pra ganhar o dinheiro já apurado de que trabalhar na roça e risca não ter nada, mas muita gente não pensa assim não $[\ldots]^{9}$.

Nessa região, a produção familiar enfrenta as adversidades das condições naturais do lugar, pelo tipo de vegetação da Caatinga, com baixa precipitação pluviométrica, além da instabilidade gerada pela fragilidade das condições econômicas, educacionais e tecnológicas. A esse respeito, a Companhia de Desenvolvimento e Ação Regional (CAR), órgão do governo estadual da Bahia, desenvolveu projeto de extensão, de 2008 a 2011, nessas comunidades, com o objetivo de ensinar e de colocar em prática conhecimentos sobre quintais produtivos (para as mulheres) e sobre criação de pequenos animais (para os homens). Também distribuiu mudas de plantas e incentivou os moradores a fundar a Associação dos Pequenos Agricultores de Jacó e Poço Dantas. A iniciativa de formação de uma associação contribuiu para o fortalecimento político dos moradores. Eles tomaram para si essa ação e foram em busca de recursos e de estratégias alternativas para a construção de um projeto emancipatório, para a vida das famílias. A perspectiva de "ajuda mútua", que caracteriza a cultura camponesa, pode ser verificada, como indica Tardin (2012, p. 181), com a "formalização de sistemas organizativos voltados para o alcance de resultados econômicos mais vantajosos", como associações comunitárias e cooperativas. Entretanto, esse projeto esbarrou nas contradições do

\footnotetext{
${ }^{9}$ Entrevista concedida pela moradora Rosa, no documentário A luta da vida da gente: História,
} Trabalho e Educação em comunidades rurais (A LUTA..., 2014). 
capitalismo, que produz um perverso processo social que desestrutura o universo das relações pessoais dos indivíduos (ALVES; ALMEIDA, 2014). Além dos conflitos com os modos de vida próprios do mundo rural, considerados por muitos como símbolo de atraso, é premente a necessidade de busca de trabalho em outros lugares.

Em grande parte, a satisfação das necessidades básicas de sobrevivência das famílias é feita fora da roça, também pelas aposentadorias e por recursos das políticas sociais. Muitas vezes, é preciso sair para trabalhar fora da comunidade. Contudo, persiste sempre a esperança e a resistência em retornar ao lugar, como explica uma das moradoras "A gente nasceu e criou aqui, né, a gente gosta daqui, né, do lugar que a gente nasceu. Eu lhe disse que eu sair fora muitos anos pra cuidar dos filhos, pra trazer sempre as coisas pra casa, mas o lugar que a gente nasceu é muito bom pra gente morar" (A LUTA..., 2014) $)^{10}$.

Em um passeio porta adentro, nas casas dos grupos familiares das comunidades de Planalto, observamos um modo de vida arranjado e provisório, mas, ao mesmo tempo, um lugar de acolhimento para quem visita ou para quem tem familiaridade com os moradores. José de Souza Martins (1998, p. 695) descreve realidade semelhante, quando observa os modos de vida de gente simples das cidades do interior do Nordeste. As casas são distintas entre si e evidenciam a existência de condições econômicas diferentes entre os grupos familiares, atestando a existência de uma certa hierarquia entre eles, em termos de estrutura ocupacional e nível de renda. Por exemplo, há casas que possuem instalações sanitárias, portas nos cômodos, fogão a gás e a lenha, geladeira, televisão, máquina de lavar e computador. Outras não possuem sanitários, somente o fogão a lenha, televisão e as entradas dos quartos são fechadas com cortinas.

É também interessante chamar a atenção para a marcante presença dos símbolos religiosos nas paredes de todas as casas, em acessórios usados pelas mulheres, nas roupas, nos calendários, nas estatuetas, como diferentes formas de as pessoas manifestarem sua religiosidade e seu fervor. Essa característica, própria "das tradições sertanejas" (MARTINS, 1998, p. 690), revela um modo de vida desse povo, em constante devoção, esperança e fé.

\footnotetext{
${ }^{10}$ Entrevista concedida pela moradora Edilene, no documentário A luta da vida da gente: História, Trabalho e Educação em comunidades rurais (A LUTA..., 2014).
} 
A presença da antena parabólica, da TV e do telefone celular evidencia a não separação entre o urbano e o rural, entre o tradicional e o moderno. O modo de vida segue os costumes típicos da cultura nordestina, que lembram o tempo das chuvas, o tempo do São João. Porém, o modo de agir, de vestir dos jovens e os artigos dentro das casas sofrem influências da vida da cidade, construindo um elo entre as pessoas das comunidades e o mundo das mercadorias. Por exemplo, observamos a reutilização de objetos para a execução de funções diferentes das originalmente previstas, como a transformação de peneiras de cessar grãos ou areia em escorredor de pratos; a transformação de latas vazias de extrato de tomate em canecas, evidenciando "o que é reutilizado" (MARTINS, 2011, p. 33).

Figura 5 - A casa e os símbolos religiosos. Comunidade de Boa Vista, em Planalto -BA

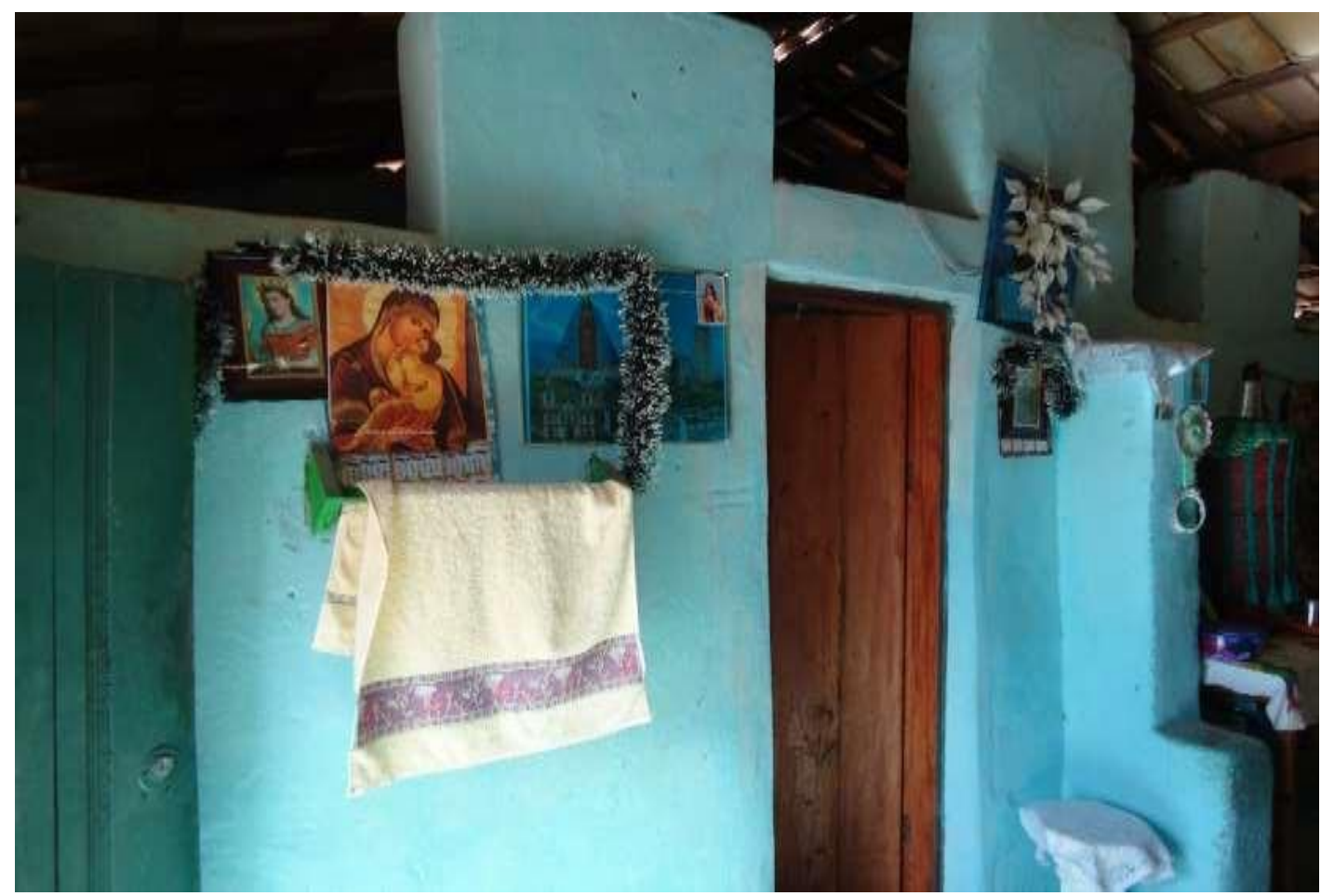

Fonte: Foto de Juliana Pereira Barbosa (2012). 
Figura 6 - Sala de visitas de uma casa na Comunidade Poço Dantas, em Planalto -BA

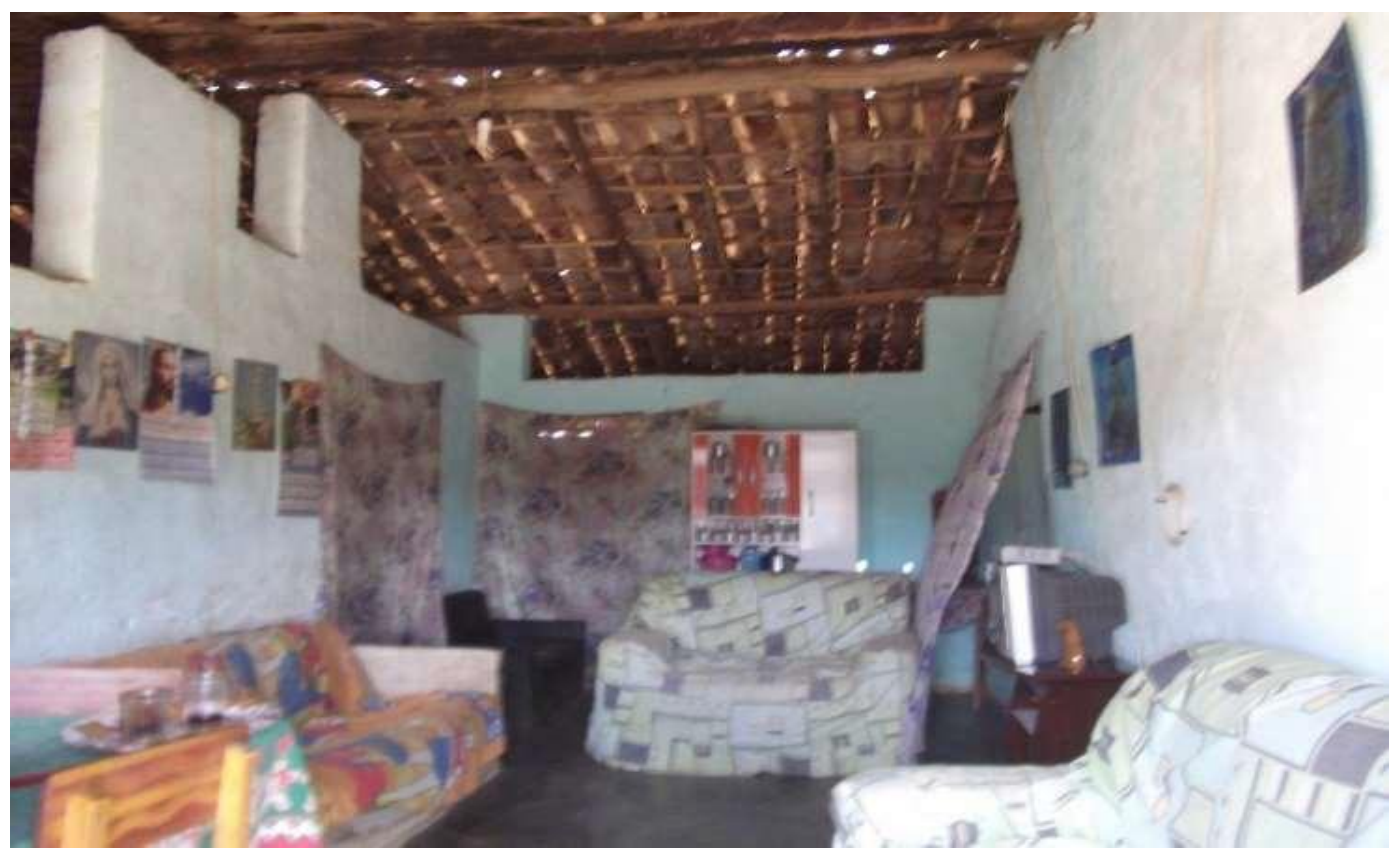

Fonte: Foto de Ediléia Rodrigues Lima (2012).

Figura 7 - A louça escorrendo na peneira. A cozinha "ao ar livre" integrada à natureza. Comunidade Poço Dantas, em Planalto -BA

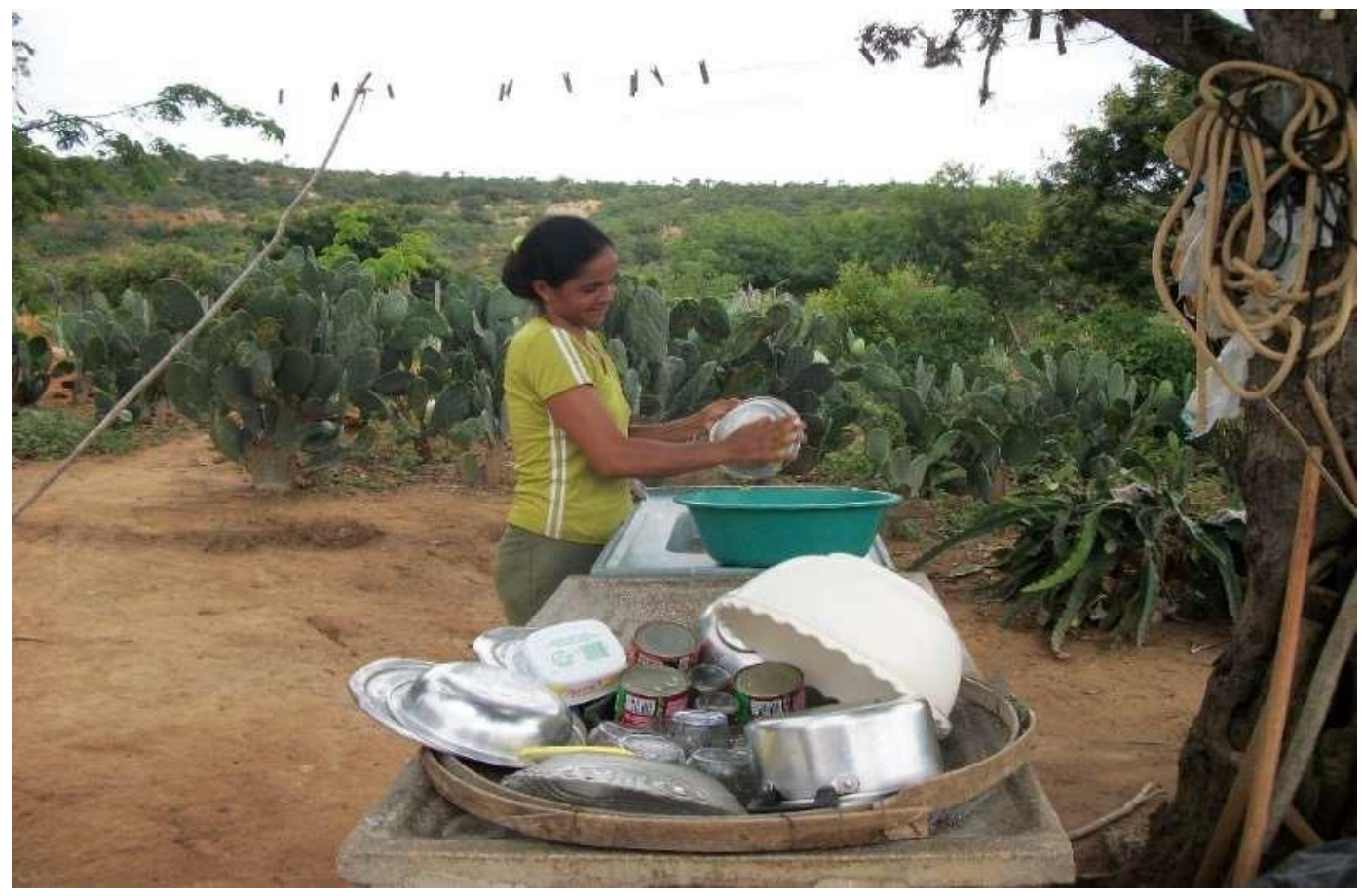

Fonte: Foto de Tânia Maria Rodrigues da Rocha (2013). 
Ainda que esteja claro, entre os moradores, a apropriação dos modos de viver do mundo urbano, por meio do uso e do consumo de mercadorias - a exemplo do celular, das motocicletas - os modos de vida tradicional e o sentimento de pertencimento ao lugar permanecem. Martins (1998, p. 692) lembra que as transições de vida e de mentalidade que ocorrem nas "populações regionais, de modo algum significam que houve grandes transformações nos costumes e nas tradições".

Em comunidades na região de Planalto (BA), essas formas específicas de modos de vida rural originaram a cooperação junto a uma associação local. Nessa associação, além do desenvolvimento das atividades de lazer, de reuniões com os associados para discutir os problemas das comunidades, os moradores conseguiram conquistas relacionadas a projetos coletivos de produção da vida social. Um exemplo são as parcerias para a construção de tanques de captação de água da chuva com a Articulação Semiárido Brasileiro (ASA), formada por uma rede de sindicatos rurais, associações de agricultores e agricultoras, cooperativas, organizações não governamentais (ONGs) e Organização da Sociedade Civil de Interesse Público (OSCIP). Como lembra Tardin (2012, p. 183) sobre a cultura camponesa, "do imediato familiar, as relações se estendem para o plano da comunidade, como espaço de vizinhança, da realização do trabalho solidário e cooperado e da sociabilidade mais intensa."

A dissertação de mestrado de Urania Teixeira Amaral (2016) revela que, num outro local, no povoado de Itaipu (BA), também região de caatinga, os grupos familiares apresentam a característica particular de serem compostos por famílias extensas, que mantêm proximidade entre as casas dos parentes e que estabelecem laços afetivos com o lugar. Ao lado disso, o ciclo de vida dos moradores também se faz pela migração temporária. Os homens vão trabalhar na construção civil e as mulheres como empregadas domésticas. Outro exemplo são as migrações anuais para as lavouras de café, em regiões circunvizinhas, com o objetivo de trabalhar no processo de colheita até o término da safra, retornando, ao final do trabalho, para o povoado. Tais trabalhadores(as) não migram livremente, mas são condicionados(as) pelo sistema capital. Essa realidade confronta com o modo de vida no povoado, que se caracteriza pelas estratégias associativas das famílias com seus vizinhos e seus 
parentes. Abandonam, ainda que temporariamente, a produção autônoma de sua existência "para a reprodução de um modo de vida compatível com a ordem social institucionalizada por aqueles que são os seus opressores" (WELCH et al., 2009, p. 13).

Depoimentos de trabalhadores(as) que foram trabalhar em São Paulo, segundo Amaral (2016, p. 70), evidenciam o quanto eles(as) "se sentiram muitas vezes, 'estranhos' num ambiente totalmente diferente do que estavam habituados". A grande metrópole produz um "processo de estranhamento do cidadão diante da cidade", como explica Ana Fani Carlos (2007, p. 38), e os sujeitos não se reconhecem como habitantes daquele lugar. "O processo de mobilidade do trabalho é difícil para os trabalhadores, se levado em conta a representação simbólica que construíram ao longo de um tempo histórico com o lugar e os grupos sociais com os quais conviveram" (AMARAL, 2016, p. 49).

Em outra localidade, no Assentamento da Fazenda Nova Ipiranga, município de Camacã, região sul da Bahia, onde vivem trabalhadores assentados, conforme a pesquisa de campo desenvolvida por Claudete Ramos de Oliveira (2018), há uma associação de moradores assentados, desde 1998, que garante atividades coletivas para os trabalhadores e suas famílias, ainda que rudimentares e reconhecidamente insuficientes pelos próprios moradores. Receberam os lotes por meio do Instituto Nacional de Colonização e Reforma Agrária (INCRA) sem, entretanto, ganhar os direitos trabalhistas por parte do antigo proprietário. O que caracteriza esse lugar como uma comunidade associada são as moradias. Dividem o mesmo espaço, quatro grupos de moradias: dois grupos que já viviam na fazenda antes dela se constituir em um assentamento e dois grupos que se mudaram para lá após o governo federal constituir o assentamento e formar a associação de moradores. $O$ assentamento possui uma escola municipal, que atende crianças até $05^{\circ}$ ano do Ensino Fundamental; igrejas de denominações diferentes - Católica e Protestante organizadas a partir das necessidades dos moradores e pelos próprios interessados. A associação reúne os moradores que discutem as necessidades coletivas como financiamentos, formação para o trabalho rural e participação em eventos do Movimento dos Trabalhadores Rurais Sem Terra (MST) regional. Os assentados se autodenominam trabalhadores rurais assentados. A falta de documentos oficiais 
definindo que pedaço de terra cabe a cada família provoca discussões, divergências e incredulidade de que um dia venham a obter o documento de posse.

A possibilidade da posse da terra para realização de um projeto de vida coletivo, orientado pelos valores da ética camponesa, propicia aos próprios trabalhadores se contraporem a formas de dominação da grande propriedade, "concebida como destruidora da dignidade social" (WELCH et al., 2009, p. 15), e a situações de exploração e humilhação que sofreram pelos proprietários das fazendas de cacau.

As mulheres trabalham no lote da família e quando há necessidade, por falta de renda da terra, oferecem sua força de trabalho na zona urbana da cidade, normalmente como empregadas domésticas. Quando jovens, trabalham em pequenas lojas e recebem valores insignificantes. Segundo as próprias trabalhadoras, "acabam pagando para trabalhar", pois gastam com o transporte e a alimentação.

Em outro assentamento na mesma região, na Fazenda Auxiliadora, há três grupos de moradias, um deles pré-existente ao assentamento. A associação promove, junto à Secretaria de Governo Estadual, um projeto de piscicultura para os jovens trabalhadores rurais, mas esse tipo de cultivo não faz parte da cultura e do modo de viver dessas pessoas. Eles são, tradicionalmente, cacauicultores. Essa situação causou prejuízos para a comunidade e desânimo entre os(as) trabalhadores(as) de continuar desenvolvendo o trabalho. Há um secador e despolpador do café que é produzido no assentamento, no entanto, muitos preferem vender o café ainda "mole" aos atravessadores, como uma forma de obtenção de dinheiro mais rápido. De acordo com Oliveira (2018), essa realidade desqualifica a existência do projeto associado. Parece que esses projetos de extensão rural, fundamentalmente, são caracterizados pelos trabalhadores como uma agressão as suas próprias relações com a terra e ao sentimento de pertencimento ao lugar, ou seja, eles impõem uma luta em defesa de um modo de vida.

Ainda no Estado da Bahia, em uma Comunidade Remanescente de Quilombo, no município de Vitória da Conquista, segundo a dissertação de mestrado desenvolvida por Tania Maria Rodrigues Rocha (2015, p. 12), os moradores vivem uma relação social construída no trabalho coletivo na agricultura familiar de subsistência, entre os grupos familiares, com uso de técnicas tradicionais, "movidos 
por um sentimento de pertença [...] um comprometimento com o outro, e na partilha da terra". Os costumes introduzidos pelos antepassados são ensinados aos mais jovens, por meio da oralidade, junto aos mais velhos, a fim de assegurar a preservação da memória desse povo. Por exemplo, uma das tradições guardadas pelos moradores do quilombo é o casamento entre parentes, com a finalidade de preservar as famílias e a posse da terra. Além disso, para eles, a instituição social do casamento tem um sentido simbólico e cultural. O "exemplo disso é a confecção do vestido da noiva por uma única senhora costureira da comunidade, que além de costurar o vestido, é testemunha dos casamentos, tornando-se madrinha da maioria [...]" das noivas (ROCHA, 2015, p. 66).

A manutenção da "cultura costumeira" (THOMPSON, 1998) significa a afirmação de um modo de vida, preservando as tradições, os costumes, a memória e a força de um povo perante a sociedade em geral. $O$ significado da terra e a sua conquista para a comunidade permitem construir um projeto coletivo de vida e de trabalho, que, quiçá, possa se tornar parte integrante de um projeto maior de homens e mulheres assumirem plenamente o controle do próprio processo de trabalho - projeto esse que se constitui como principal objetivo da luta da classe trabalhadora.

\section{Para concluir...}

O agricultor conhece as suas estações, o marinheiro conhece seus mares, mas ambos permanecem mistificados em relação à monarquia e à cosmologia (THOMPSON, 1981, p. 16).

Thompson (1981) convida-nos a refletir que a experiência do trabalho é válida dentro de determinados limites. Podemos dizer que entre a experiência vivida, a experiência percebida e a experiência modificada, há um grande caminho a percorrer, o que requer, entre outros elementos, que homens e mulheres das comunidades tradicionais tenham acesso a uma educação que lhes permita compreender e confrontar seus modos de vida com o modo capitalista de produção da existência humana. Afinal, como é possível pensar um projeto de emancipação humana sem considerar que tanto as contradições fundamentais, como as contradições mutáveis do capitalismo, indicadas por Harvey (2016), afetam sobremaneira seus modos de vida? Na verdade, essas contradições são 
constitutivas da totalidade social, na qual homens e mulheres se produzem e são produzidos. O fim dessas contradições pressupõe o fim do próprio capitalismo, cujo crescimento exponencial tem ameaçado a vida de todos os seres da natureza.

Historicamente, as políticas agrárias brasileiras perpetuam as grandes propriedades e não estimulam 0 acesso à posse da terra por parte dos desapropriados, ou dos pequenos donos de terra, nem a formas de investimentos em capitais tecnológicos e educacionais (WANDERLEY, 2009). As classes dominantes buscam controlar a força de trabalho e a formação de um exército de reserva de desempregados ou subempregados. Nesse sentido, as formas de sociabilidades comunitárias são atravessadas por formas de sociabilidade impostas pelo capital.

Embora, muitas vezes, esses trabalhadores e essas trabalhadoras sejam obrigados(as) a vender sua força de trabalho para realização de trabalho assalariado precário, afirmam-se por meio de relações econômicas e culturais construídas no âmbito da comunidade, com o objetivo de garantir a reprodução ampliada da vida, e não do capital. Essas relações são estabelecidas mediante estreitos vínculos com a sociedade em geral, tanto pelo acesso aos meios de comunicação de massa, como pelo consumo de mercadorias produzidas por empresas capitalistas. Ali, ainda que em menor escala, o fetiche da mercadoria também se faz presente.

Acreditamos que os espaços/tempos das comunidades tradicionais, onde se verificam experiências do trabalho de produzir a vida associativamente (TIRIBA; FISCHER, 2013, 2015), podem ser considerados como espaços/tempos de formação humana tensionados pelas contradições entre capital e trabalho. Embora o objetivo das atividades de trabalho seja a reprodução ampliada da vida, o modo de produção capitalista, por ser hegemônico a outros modos de produção da vida social, vai criando as condições objetivas e subjetivas para que homens e mulheres de comunidades tradicionais se submetam, de forma subordinada, aos processos de reprodução ampliada do capital. Nessa perspectiva, o 'trabalhar para viver' vai se transformando em trabalho-mercadoria, cujo objetivo é a produção de valores para o mercado capitalista. Na luta cotidiana pela sobrevivência, as mediações primárias são atravessadas por mediações do capital.

De qualquer maneira, podemos afirmar que os modos de vida comunitários e observados nas pesquisas em comunidades tradicionais em Mato Grosso e no Pará, 
como também na Bahia, evidenciam que as relações entre seres humanos, natureza e cultura não correspondem ao modo dominante, instituído pelo capital. Trata-se de um fenômeno extremamente mutável, conforme as transformações sócio-culturais e econômicas da sociedade, o que faz com que os nexos entre trabalho, educação e sociabilidade também o sejam da mesma forma. Como nos assegura Wanderley (2000, p. 89):

\begin{abstract}
As profundas transformações resultantes dos processos sociais mais globais - a urbanização, a industrialização, a modernização da agricultura - não se traduziram por nenhuma "uniformização" da sociedade, que provocasse o fim das particularidades de certos espaços ou certos grupos sociais.
\end{abstract}

Os povos e as comunidades tradicionais resistem, em maior ou menor grau, à contradição vital entre sociabilidades pautadas na reprodução ampliada da vida e sociabilidades pautadas na reprodução ampliada do capital. Florestan Fernandes lembra que Antonio Cândido, autor da obra clássica, Os parceiros do Rio Bonito, analisou o modo de vida dos "caipiras paulistas" e em uma de suas reflexões sobre a pequena comunidade, demonstrou o "dilema social que a civilização urbana cria para a integridade e a continuidade da cultura caipira" (FERNANDES, 1972, p. 49). Entretanto, é interessante observar que os costumes das comunidades tradicionais se mantêm, pois não é pouca a resistência dessa gente em preservar seus modos de vida baseados na solidariedade, na cooperação e na reciprocidade. Não por acaso, Thompson $(1987,1998)$ insiste que a classe é uma formação tanto econômica, como cultural e, portanto, toda luta de classes se constitui como luta por valores.

Eleger mulheres e homens trabalhadores de comunidades tradicionais como objeto/sujeito de nossas pesquisas contribui para desvelar saberes tradicionais, costumes e normas de convivência que não coadunam com a lógica perversa do capital. Sem desconsiderar a premissa das determinações econômicas como última instância, assim como Thompson, entendemos que economia e cultura não são instâncias separada da vida social. De acordo com suas próprias palavras: "é essencial manter presente no espírito o fato de os fenômenos sociais e culturais não estarem 'a reboque', seguindo os fenômenos econômicos à distância: eles estão em seu surgimento, presos na mesma rede de relações" (THOMPSON, 2001, p. 208). 
Estudos sobre cultura popular de povos e comunidades tradicionais podem contribuir para o entendimento de como a sociedade de mercado vai expandindo a assimilação de hábitos de consumo do "mundo maravilhoso das mercadorias" (MARTINS, 2012, p. 43) para essa gente, fomentando o processo de acumulação do capital. Também contribuem para evidenciar que, contraditoriamente, mulheres e homens expressam modos de vida calcados em relações econômicas-culturais não capitalistas. Tendo em conta as contribuições de Raymond Williams em relação à hegemonia, cujas estruturas internas são complexas e precisam ser recriadas continuamente, insistimos que os modos de vida, nessas comunidades tradicionais, nos asseguram que nenhum modo de produção e, portanto, nenhuma cultura dominante pode esgotar a "gama extraordinária de variações práticas e imaginadas pelas quais seres humanos se veem como capazes" (WILLIAMS, 2011, p. 59). Como pesquisadoras, nosso desafio é apreender a "estrutura na particularidade histórica do conjunto das relações sociais" (THOMPSON, 2001, p. 248).

\section{Referências}

A LUTA da vida da gente: História, Trabalho e Educação em comunidades rurais. Produção de Ana Elizabeth Santos Alves et al. Vitória da Conquista: Museu Pedagógico da UESB/PROVÍDEO, 2014. DVD.

ALVES, Ana Elizabeth S. O trabalho e a educação de mulheres em comunidades rurais: práticas de reprodução social. In: BATISTA, E. L.; MULLER, M. T. (Org.). A Educação profissional no Brasil: história, desafios e perspectivas para o século XXI. Campinas: Alínea, 2013, v. 1, p. 235-56.

. Trabalho, vida rural e educação. Revista HISTEDBR [on line], Campinas, $\mathrm{n}$.

70, p. 163-177, dez. 2016.2 Disponível em: <https://periodicos.sbu.unicamp.br/ojs/index.php/histedbr/article/view/8649214>. Acesso em: 12 dez. 2017.

ALVES, Ana Elizabeth S.; ALMEIDA, Miriam Cléa Coelho. A centralidade do trabalho na determinação da mobilidade territorial dos trabalhadores. Revista HISTEDBR [on line], Campinas, n. 55, p. 250-266, mar. 2014. Disponível em:

<http://periodicos.sbu.unicamp.br/ojs/index.php/histedbr/article/viewFile/8640473/803 2>. Acesso em: 01 mar. 2014.

; SILVA, Lucineide. Notas de leitura sobre o método 'estudos de comunidade' no Brasil e o programa de pesquisas sociais do Estado da Bahia. In: MENEZES, J. M. F.; SANTANA, E. C.; AQUINO, M. S. (Org.). Educação, região e territórios: formas de inclusão e exclusão. Salvador: EDUFBA, 2013. v. 12, p. 37-59. 
AMARAL, Urânia Teixeira. Memória e Mobilidade do Trabalho no povoado de Itaipu, Município de Vitória da Conquista-BA. 2016. 115 f. Dissertação (Mestrado em Memória: linguagem e Sociedade) - Universidade Estadual do Sudoeste da Bahia (UESB), Vitória da Conquista, 2016.

BARRA, José D. F. (Org.). Prá onde sopram os ventos. Práticas educativas dos pescadores de Cametá. Cametá: UFPA Cametá Cuntins, 2015.

BRAGA, Gustavo B.; FIÚZA, Ana Louise C.; ALMEIDA, Paula Cristina R. O conceito de modo de vida: entre traduções, definições e discussões. Sociologias, Porto Alegre, ano 19, n. 45, p. 370-396, maio/ago. 2017. Disponível em:

<http://seer.ufrgs.br/index.php/sociologias/article/view/65878>. Acesso em: $13 \mathrm{fev}$. 2018.

CARLOS, Ana Fani A. O lugar no/do mundo. São Paulo: FFLCH, 2007. Disponível em:

$<$ <ttp://www.gesp.fflch.usp.br/sites/gesp.fflch.usp.br/files/O_lugar_no_do_mundo.pdf >. Acesso em: 01 jan. 2018.

CRUZ, Valter do Carmo. Povos e comunidades tradicionais. In: CALDART, Roseli et al. (Org.). Dicionário da Educação do Campo. Rio de Janeiro: EPSJV; São Paulo: Expressão Popular, 2012. p. 594-600.

COMERFORD, John C. Como uma família. Sociabilidade, territórios de parentesco e sindicalismo rural. Rio de Janeiro: Relume-Dumará, 2003.

DIEGUES, Antônio C. Modelo econômico e os modos de vida: confrontos e alternativas no sul do Pará. In: DIEGUES, A. C. S.; MILLIKAN, B. (Org.). Desmatamento e modos de vida na Amazônia. São Paulo: NUPAUB, 1999.

FERNANDES, Florestan (Org.). Comunidade e Sociedade no Brasil: leituras básicas de introdução ao estudo macro-sociológico do Brasil. São Paulo: Cia Editora Nacional, 1972.

GUERRA, Isabel. Modos de vida: novos percursos e novos conceitos. Sociologia Problemas e Práticas, n. 3, p. 59-74, 1993. Disponível em: <https://repositorio.iscteiul.pt/handle/10071/932>. Acesso em: 15 fev. 2018.

HARVEY, David. 17 Contradições e o fim do capitalismo. São Paulo: Boitempo, 2016.

MARQUES, Marta Inez Medeiros. Lugar do modo de vida tradicional. In: OLIVEIRA, A. U.; MARQUES, M. I. M. (Org.). O campo no século XXI: território de vida, de luta e de construção da justiça social. São Paulo: Casa Amarela; Paz e Terra, 2004. p. 145158.

MARTINS, Egídio. Pescadores artesanais da colônia Z-16: relações de produçãoformação e práxis política. 2017. 211 f. Tese (Doutorado em Educação) - Instituto de Ciências da Educação, Universidade Federal do Pará, Belém, 2017. 
MARTINS, José de Souza. A vida privada nas áreas de expansão da sociedade brasileira. In: NOVAIS, F. A.; SCHWATCZ, L. M. (Org.). História da vida privada. São Paulo: Companhia das Letras, 1998. p. 659-726.

. A sociabilidade do homem simples: cotidiano e história na modernidade anômala. 3.ed. São Paulo: Contexto, 2011. . Exclusão social e a nova desigualdade. São Paulo: Paulus, 2012.

NEVES, Camilla. A produção associada em Capão Verde: entre bananas, saberes e utopias. Cuiabá: Ed. UFMT, 2013.

OLIVEIRA, Claudete R. A invisibilidade do trabalho das mulheres: as memórias das trabalhadoras rurais acerca das relações de trabalho na lavoura cacaueira. 2018. 104 f. Dissertação (Mestrado em Memória, linguagem e Sociedade) - Universidade Estadual do Sudoeste da Bahia, Vitória da Conquista, 2018.

ROCHA, Tania Maria Rodrigues da. Memória, Trabalho e Envelhecimento de Mulheres Negras Idosas em uma Comunidade Remanescente de Quilombo São Joaquim de Paulo em Vitória da Conquista - Bahia. 2015. 116 f. Dissertação (Mestrado em Memória, linguagem e Sociedade) - Universidade Estadual do Sudoeste da Bahia, Vitória da Conquista, 2015.

RODRIGUES, Doriedson. Estado, saberes e luta de classe na materialidade histórica dos pescadores artesanais. In: BARRA, J. D. F. (Org.). Prá onde sobram os ventos. Práticas educativas dos pescadores de Cametá. Cametá: UFPA Cametá Cuntins, 2015. p. 29-48.

SATO, Michèle et al. Mapa dos conflitos ambientais no Estado de Mato Grosso. Cuiabá: UFMT, 2013.

TARDIN, José M. Cultura Camponesa. In: CALDART, R. et al. (Org.). Dicionário da Educação do Campo. Rio de Janeiro: EPSJV; São Paulo: Expressão Popular, 2012. p. 178-186.

TIRIBA, Lia; FISCHER, Maria Clara B. Aprender e ensinar a autogestão: espaços/tempos do trabalho de produzir a vida associativamente. Perspectiva, Florianópolis, v. 31 n. 2, 527-551, maio/ago. 2013.

Espaços/tempos milenares dos povos e comunidades tradicionais: notas de pesquisa sobre economia, cultura e produção de saberes. Revista Educação Pública, Cuiabá, v. 24, n. 56, p. 405-428, maio/ago. 2015.

; SANTANA, Fernanda. Do diário de campo: conversas com pescadoras/es do Pantanal Mato-grossense sobre cultura do trabalho. Trabalho \& Educação, Belo Horizonte v. 26, n. 2, p. 65-84, mai/ago. 2017. Disponível em:

$<$ https://seer.ufmg.br/index.php/trabedu/article/view/8010/7637>. Acesso em: 05 fev. 2018. 
THOMPSON, Edward P. A miséria da teoria: ou um planetário de erros. Rio de Janeiro: Zahar, 1981.

. A formação da classe operária inglesa. Rio de Janeiro: Paz e Terra, 1987. v.

1.

Costumes em comum. Estudos sobre a cultura popular tradicional. São Paulo: Companhia das Letras, 1998.

A peculiaridade dos ingleses e outros artigos. Organização de Sergio Silva e Antônio Negro. Campinas: Unicamp, 2001.

WANDERLEY, Maria de Nazareth Baudel. A emergência de uma nova ruralidade nas sociedades modernas avançadas - o "rural" como espaço singular e ator coletivo. Estudos Sociedade e Agricultura, n. 15, p. 87-145, out. 2000. Disponível em:

<http://agriculturasamazonicas.ufpa.br/PDF'S/AA_selecao/2011/Wanderley\%201996. pdf>. Acesso em: 01 abr. 2011.

- O mundo rural como um espaço de vida: reflexões sobre a propriedade da terra, agricultura familiar e ruralidade. Porto Alegre: UFRGS, 2009.

WELCH, Clifford Andrew et al. Camponeses brasileiros: leituras e interpretações clássicas. São Paulo: Editora UNESP; Brasília: Núcleo de Estudos Agrários e Desenvolvimento Rural, 2009. v. 1. Disponível em: <http://www.iicabr.iica.org.br/wpcontent/uploads/2014/03/Camponeses-Brasileiros-vol-1-NEAD.pdf>. Acesso em: 10 fev. 2018.

WILLIAMS, Raymond. Cultura e materialismo. São Paulo: Editora Unesp, 2011.

Recebido em: 22 de agosto de 2018. Aprovado em: 28 de setembro de 2018. Publicado em: 22 de novembro de 2018. 